\section{PENATAAN KORIDOR SULTAN KHAIRUN UNTUK MENCIPTAKAN KONDISI TERMAL OPTIMAL}

Article history

Received

Received in revised form

Accepted

Firdawaty Marasabessya*, Asri A Muhammada

aUniversitas Khairun, Ternate, Indonesia
*Corresponding author mfirdawaty@gmail.com

\begin{abstract}
The development of a city results the increasing of the temperature of the city. This condition is commonly known as the Urban Heat Island effect. This has an impact on the activities that occur in the city space. The Sultan Khairun Corridor (one of the city spaces / street) which is oriented towards North-South, currently, it has grown rapidly and is dominated by commercial functions and is visited by the people of Ternate city. Related to this condition, thermal comfort is an important and available matter for users. This study aims to determine the hardscape and softscape arrangement of the thermal comfort aspects of the city public space. The method used is the empirical method measurement and simulation using Envi-MET software. The results show that the corridor of Jalan Sultan Khairun is dominated by buildings with 1-2 floors high and minimal vegetation which is only found on one side of the road so that the average temperature is 32 degrees during the daytime heat. Simulation of a corridor with dense vegetation and low building density on both sides so that the wind moves so that it can reduce heat by the sun.

Keywords: corridor, thermal comfort, building.

Abstrak

Perkembangan suatu kota mengakibatkan meningkatnya suhu udara di kota tersebut. Kondisi ini biasa dikenal sebagai efek Urban Heat Island. Hal ini berdampak pada aktivitas yang terjadi di ruang kota. Koridor Sultan Khairun (salah satu ruang kota/street) yang berorientasi UtaraSelatan, saat ini telah berkembang pesat dengan didominasi oleh fungsi komersial dan ramai dikunjungi oleh masyarakat kota Ternate. Terkait dengan hal tersebut kenyamanan termal menjadi suatu hal yang penting dan tersedia bagi pengguna. Penelitian ini bertujuan untuk mengetahui penataan hardscape dan softscape terhadap aspek nyaman termal pada ruang publik kota. Metode yang digunakan adalah metode pengukuran empirik dan simulasi menggunakan software Envi-MET. Hasil penelitian menunnukkan bahwa pada koridor Jalan Sultan Khairun didominasi oleh bangunan dengan ketinggi 1-2 lantai dan minim vegetasi yang hanya terdapat pada salah satu sisi jalan sehingga temperature rata-rata 32 derajat pada siang hari lebih panas. Simulasi koridor dengan vegetasi rapat dan kerapatan bangunan rendah dikedua sisinya agar angin bergerak sehingga dapat mengurangi panas oleh sinar matahari.
\end{abstract}

Kata kunci: koridor, kenyamanan termal, bangunan.

(C) 2021 Penerbit Fakultas Teknik Unkhair. All rights reserved

\title{
1.0 PENDAHULUAN
}

Indonesia digolongkan ke dalam iklim tropis lembab, dengan intensitas radiasi matahari, temperatur udara dan curah hujan yang relatif tinggi serta keadaan langit yang senatiasa berawan [1]. Keadaan demikian berpengaruh terhadap akitivitas perkotaan yang ada di Indonesia. Kota sebagai tempat hidup, bekerja dan rekreasi bagi manusia sangat membutuhkan kenyamanan, baik itu nyaman visual, nyaman gerak maupun nyaman termal. Faktor-faktor yang mempengaruhi kenyamanan termal antara lain radiasi matahari (temperatur), gerakan udara dan kelembaban serta tingkat kebersihan udara. Menurut Satwiko [2], untuk mengendalikan laju peningkatan 
temperatur ada 3 (tiga) hal yang perlu diperhatikan yaitu durasi penyinaran matahari, intensitas penyinaran matahari, dan sudut jatuh sinar matahari. Selain itu juga pergerakan udara juga sangat membantu dalam mengendalikan/menurunkan temperatur yang ada. Ruang publik sebagai salah satu elemen kota juga sangat membutuhkan kondisi termal yang nyaman. Tatanan bangunan dan vegetasi yang baik akan sangat membantu dalam menciptakan suatu kondisi yang nyaman termal.

Koridor Sultan Khairun (Jl. Sultan Khairun, dari perempatan Benteng Oranje sampai pada jalan Djabir Sjah/Kedaton) merupakan kawasan di bagian tengah kota Ternate dan merupakan sebuah kawasan yang mulai mengalami pertumbuhan cepat dan mengarah ke fungsi komersial. Selain itu terdapat beberapa fasilitas pendidikan dan perkantoran. Tumbuhnya pusat-pusat komersial di koridor ini membuat kawasan semakin padat akan berbagai aktifitas dan menyebabkan meningkatnya intensitas pengguna ruang jalan. Pertumbuhan yang tidak dibarengi dengan rekayasa naungan dan penataan vegetasi yang baik mempengaruhi kualitas termal ruang pada koridor yang menyebabkan ketidaknyamanan pengguna jalan, utamanya para pejalan kaki.

Di kawasan urban daerah tropis lembab seperti Ternate, pada siang hari cuaca cerah radiasi matahari langsung sangat menyengat (pada jam 12.00) dan banyak dihindari orang. Koridor Sultan Khairun yang secara geografis membentang dari arah utara selatan sehingga kedua sisi jalan senantiasa mendapat sinar matahari secara terus menerus mulai dari terbit sampai dengan tenggelamnya matahari. Selain itu juga keberadaan jalan ini memotong aliran/pergerakan angin yang datang dari arah timur begitu juga yang dari barat. Sehingga dibutuhkan perlakuan khusus untuk menciptakan kondisi termal yang nyaman bagi pengguna yang beraktifitas di tempat ini.

Ada tiga elemen urban yang dominan berpengaruh pada termal mikro yaitu bangunan, area perkerasan (konblok atau aspal) dan area hijau (vegetasi) [3]. Bangunan dan area perkerasan memberi kontribusi perubahan temperatur melalui perpindahan panas secara konvensi dan radiasi yang dipengaruhi oleh properti materialnya. Panas yang diserap pada siang hari membuat permukaan area perkerasan menjadi naik suhunya dan selanjutnya angin di sekitar permukaan akan menyapu dan menyerap panas, secara konveksi suhu udara disekitar permukaan menjadi ikut naik. Penelitian menemukan perbedaan temperatur antara daerah Central Bussiness Distric dan area hijau berkisar $1-2^{\circ}$ Celsius [3]. Tujuan dari penelitian ini adalah penataan Koridor Sultan Khairun untuk mencapai kondisi termal ruang yang optimal.

\subsection{METODE PENELITIAN}

Fokus penelitian ini adalah kenyamanan termal pada ruang koridor Sultan Khairun. Metode yang digunakan adalah pengukuran empirik dan simulasi model menggunakan Envi-MET System, untuk memperlihatkan kondisi termal dan hasil analisis termal yang dilakukan dengan menggunakan data-data yang telah ada.



Gambar 1 Skema Penelitian 


\subsection{HASIL DAN PEMBAHASAN}

Penelitian kenyamanan termal di koridor Sultan Khairun difokuskan pada dua hal sebagai berikut:

1. Menganalisis kondisi kenyamaman termal pada koridor berdasarkan hasil pengukuran empirik. Data pengukuran diambil pada 3 waktu yang berbeda yakni pagi, siang dan sore.

2. Menganalisis kondisi kenyamaman termal pada koridor menggunakan model simulasi iklim mikro dengan data iklim.

Data konfigurasi ruang pada koridor didapat dari data citra google earth dan juga survey langsung di lapangan dengan tujuan untuk validasi data. Konfigurasi ruang merupakan pola tata massa bangunan dan vegetasi dalam suatu kawasan [4]. Variabel vegetasi menjadi faktor utama, karena akan mempengaruhi pola pergerakan angin. Dari data di lapangan, maka terdapat beberapa jenis vegetasi dan memiliki tinggi yang bebeda-beda.

\subsection{Analisis Kondisi Eksisting}

Koridor Sultan Khairun merupakan jalan 2 arah (Utara-Selatan) yang memiliki 2 jalur kendaraan. Koridor yang membentang dari utara ke selatan ini merupakan koridor dengan perkembangan bangunannya cenderung vertikal hal ini terlihat dengan munculnya bangunan baru yang lebih dari satu lantai pada koridor ini.

Tatanan ruang pada koridor ini didominasi oleh bangunan pada kedua sisinya. Ketinggian bangunannya bervariasi dari 1 lantai sampai dengan 3 lantai, sebagian besarnya didominasi oleh bangunan dengan ketinggian 1 sampai 2 lantai (lihat Gambar 2). Bangunan-bangunan yang ada pada koridor ini didominasi oleh bangunan dengan fungsi hunian dan bangunan dengan fungsi komersial yakni berupa pertokoan. Berdasarkan eksisting koridornya, bangunan-bangunan yang ada di koridor ini cenderung beralih fungsi menjadi komersial karena mobilitas yang tinggi dan ramai sehingga berpengaruh juga pada perkembangan bangunan yang cenderung vertikal.

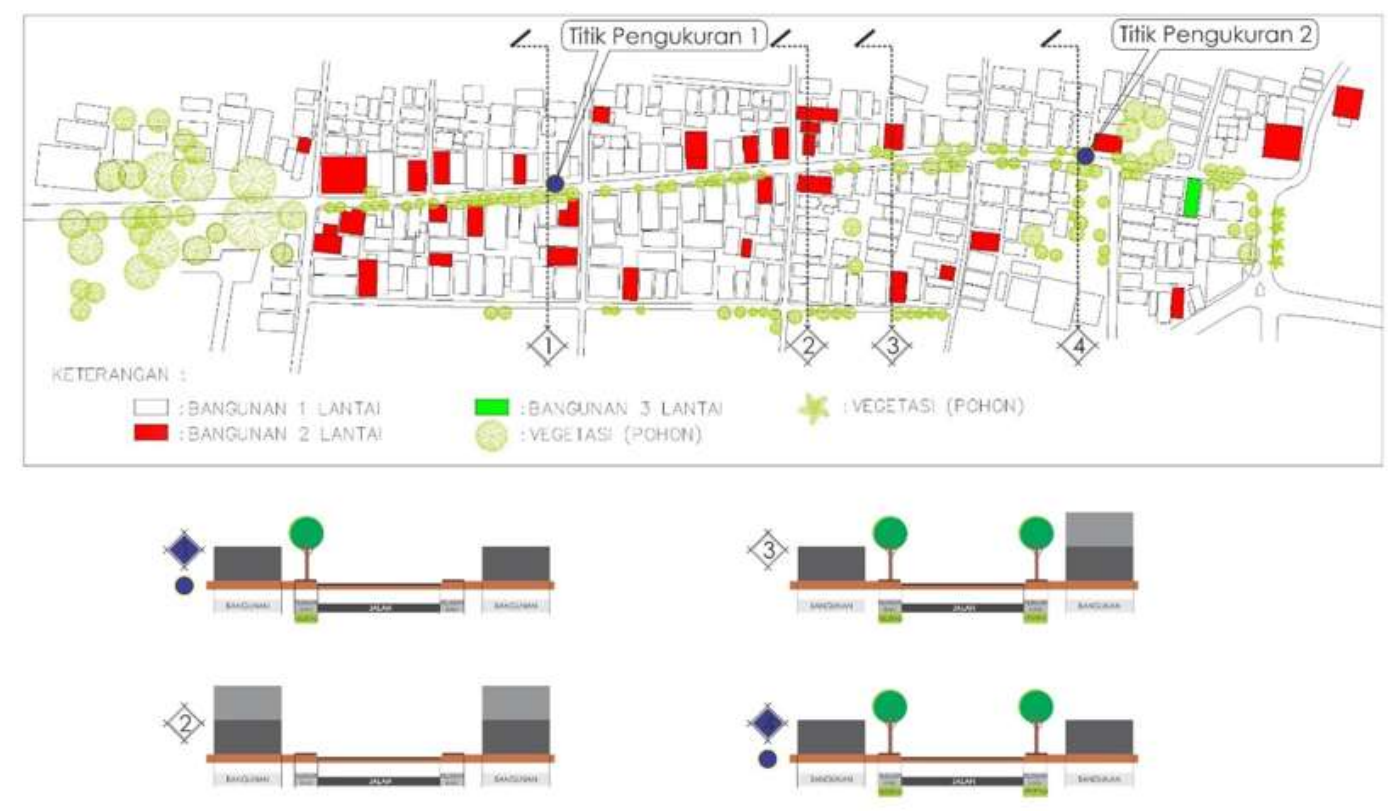

Gambar 2 Karakter Ruang Jalan dan Titik Pengambilan Data

Keberadaan vegetasi pada koridor ini juga masih minim, dimana sepanjang koridor ini tampak sedikitnya vegetasi (berupa pohon) yang memberikan teduhan bagi pengguna. Area sekitar titik pengukuran 1 (lihat kotak warna biru, bagian selatan koridor) vegetasi (pohon) hanya pada sisi timur koridor sedangkan pada area titik pengukuran 2 (lihat kotak warna hitam, bagian utara koridor) cenderung lebih merata pada kedua sisinya walaupun jaraknya masih sangat renggang. Selain itu permukaan dan dinding ruang jalan yang semua didominasi oleh material yang baik dalam memantulkan dan meningkatkan panas sinar matahari langsung yang mengenai permukaan material pada ruang jalan tersebut apalagi pada siang hari (dalam kondisi cuaca cerah) (lihat Gambar 3). 




Gambar 3. Ketinggian Bangunan dan Sebaran Vegetasi



Gambar 4 Kondisi Vegetasi Pada Area Titik Pengukuran

\subsection{Analisis Kenyamanan Termal Kondisi Eksisting}

Analisis dilakukan pada ketinggian 1,20 meter dengan asumsi bahwa pada ketinggian ini pengguna akan sangat merasakan kondisi kenyamanan termal. Karakteristik koridor ini antara lain:

1. Didominasi bangunan dengan ketinggian 1-2 lantai.

2. Area titik pengukuran 1 masih minim vegetasi, hanya pada 1 sisi yaitu pada sisi timur koridor terdapat vegetasi.

3. Area titik pengukuran 2 cenderung merata pada kedua sisi koridor namun jaraknya masih renggang.

Material permukaan koridor dari aspal (untuk jalan dengan lebar jalan 6 meter) dan paving (jalur pejalan kaki $\pm 1,20$ meter).

\subsection{Analisis Kenyamanan Termal Pada Pengukuran Titik 1}

Pengukuran dilakukan di sisi Utara koridor. Pengukuran dilakukan pada 3 waktu yang berbeda yakni pagi (dimulai dari pukul 08.30 WIT sampai dengan pukul 10.00 WIT), siang (dari pukul 11.00 WIT sampai dengan 14.00 WIT) dan sore (mulai pukul 15.00 WIT sampai dengan 17.30 WIT) pada tanggal 11 Juli 2020.

Perubahan data temperatur dan kelembanan saat pengukuran direkam tiap 10 menit. Hal ini memudahkan untuk melihat laju perubahan yang terjadi selama pengukuran yang dimulai pada pukul 08.30 sampai dengan 17.00 WIT.

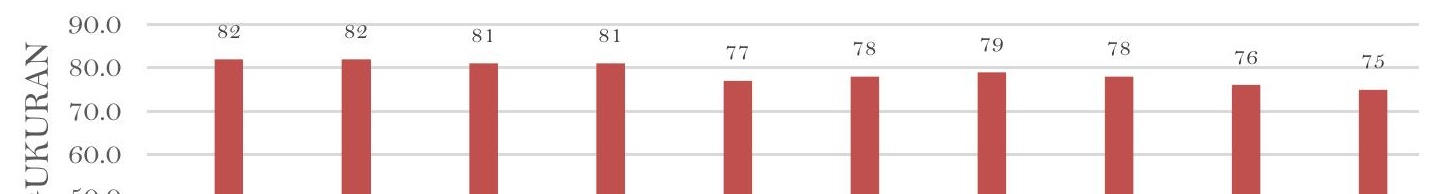


Gambar 5 Data Pengukuran Temperatur dan Kelembaban Pukul 08.30 - 10.00 WIT

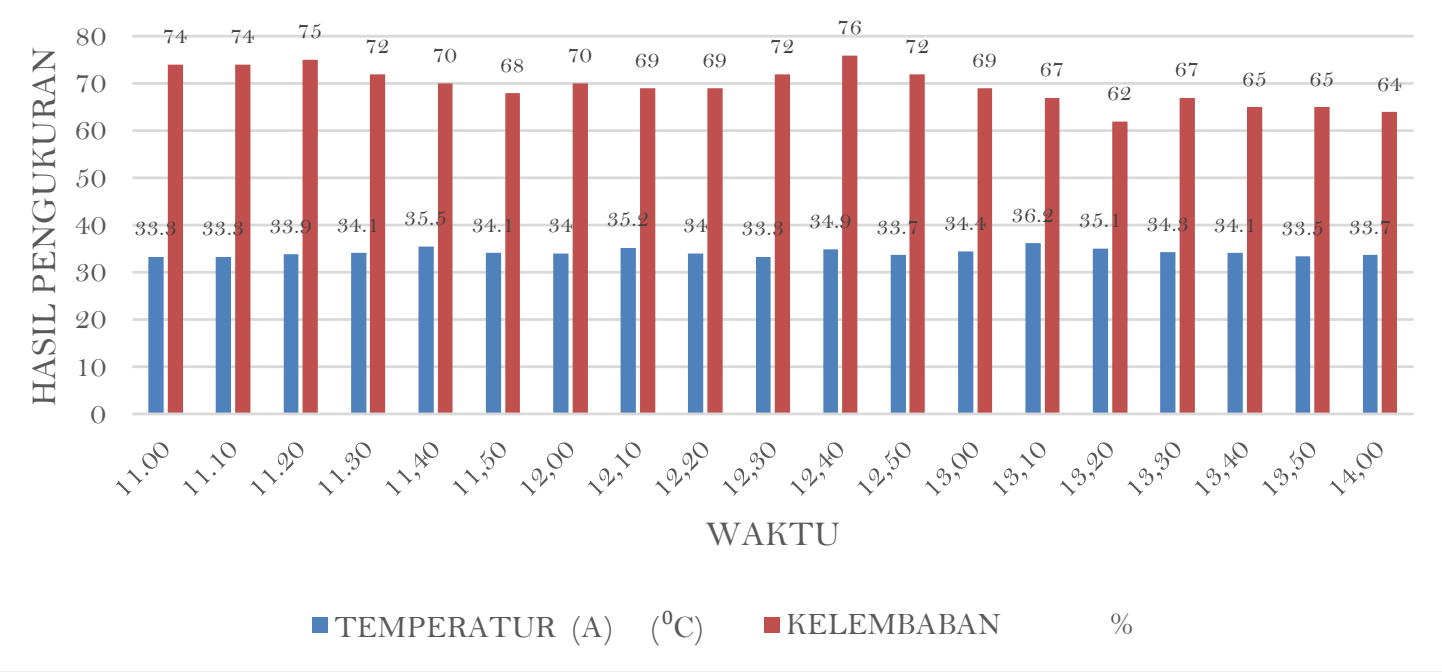

Gambar 6 Data Pengukuran Temperatur dan Kelembaban Pukul 11.00 - 14.00 WIT

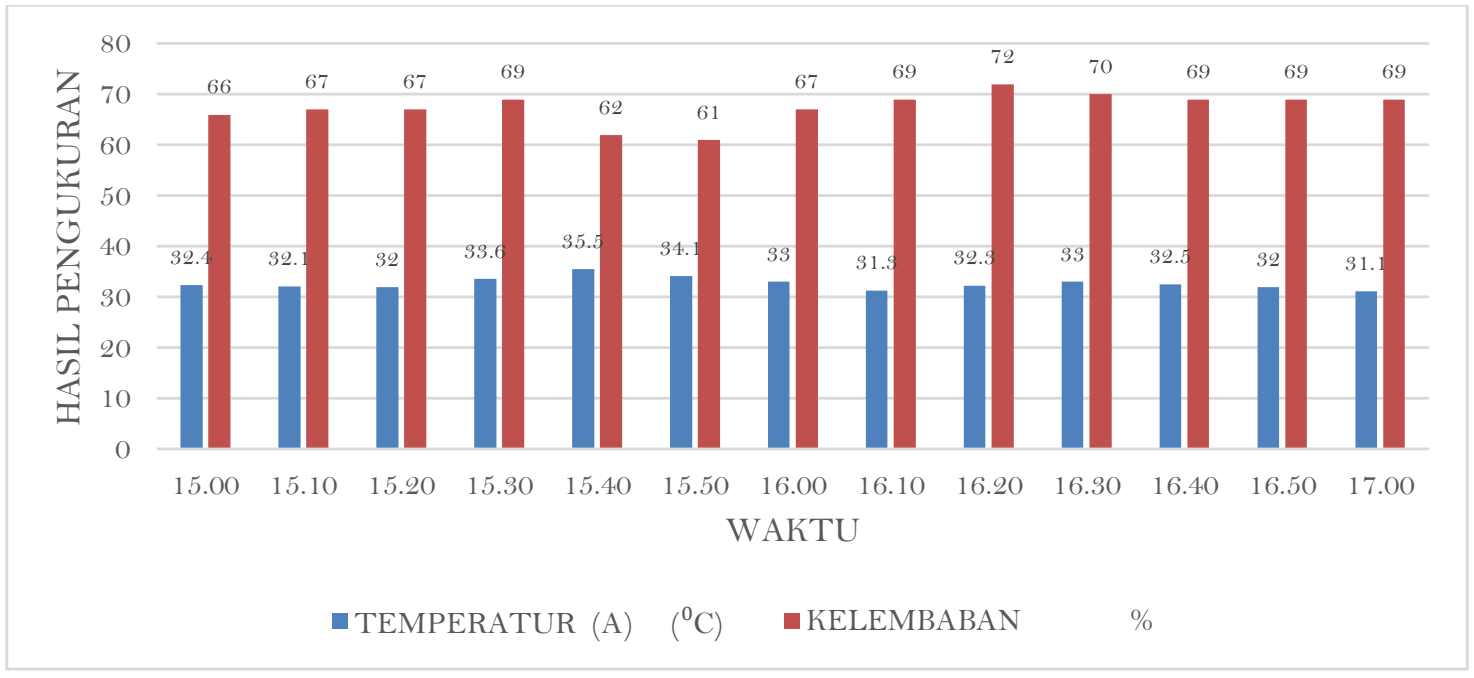

Gambar 7 Data Pengukuran Temperatur dan Kelembaban Pukul 15.00 - 17.00 WIT 
Grafik di atas (Gambar 5) menunjukan bahwa perubahan suhu dan kelembaban terjadi seiring dengan pergerakan matahari yang semakin meninggi. Temperatur pada pukul 08.30 WIT dimana awal pengambilan data berada pada $30,5{ }^{\circ} \mathrm{C}$ dan terus mengalami perubahan yang cenderung meningkat setiap 10 menit. Berdasarkan pengamatan saat pengukuran berlangsung, peningkatan temperatur terjadi saat beberapa kendaraan melewati pengamat dengan jarak yang berdekatan sehingga gas buangan kendaraan terkonsentrasi dalam jumlah banyak yang mempengaruhi temperatur pada waktu itu. Saat volume kendaraan menurun dan jarak berjauhan maka terjadi penurunan temperatur, hal ini dapat dilihat pada waktu pengukuran pukul 09.30 sampai dengan pukul 09.50 (lihat gambar 5). Kondisi ini terjadi juga pada kelembaban. Temperatur dan kelembaban rata-rata pada waktu pengukuran ini adalah $33,58^{\circ} \mathrm{C}$ dan $78,90 \%$.

Berbeda dengan kondisi pada pagi hari, seperti yang tampak pada gambar 6 di atas menunjukan bahwa kondisi di siang hari menjadi sangat jauh dari ambang atas kenyamanan termal untuk aktivitas manusia, dimana temperatur rata-rata mencapai $34,24^{\circ} \mathrm{C}$ dan kelembaban $69,47 \%$. Temperatur tertinggi pada waktu pengukuran ini adalah pukul 13.10 WIT yaitu $36,2^{\circ} \mathrm{C}$. Berdasarkan pengamatan, penurunan temperatur terjadi seiring dengan kondisi cuaca yang mendung pada saat pengambilan data. Kelembaban juga mengalami perubahan yang menunjukan grafik menurun seiring dengan peningkatan temperatur. Pada interval waktu ini, matahari berada pada puncak penyinarannya sehingga sangat mempengaruhi temperatur dan kelembaban.

Grafik (gambar 7) di atas menunjukan bahwa pada interval waktu ini temperatur udara pada penggal ini mengalami penurunan, pada pukul $15.00 \mathrm{WIT}$ temperatur berada pada $32,4^{\circ} \mathrm{C}$ dimana terus mengalami perubahan hingga $31,1^{\circ} \mathrm{C}$ pada pukul 17.00 WIT. Begitu juga dengan kelembaban. Temperatur rata-rata pada waktu ini adalah $32,68^{\circ} \mathrm{C}$ dan kelembaban rata-ratanya $67,46 \%$ Penurunan ini disebabkan oleh intensitas penyinaran matahari yang menurun menjelang malam hari. Walaupun mengalami penurunan namun kondisi ini masih jauh dari batas nyamam termal bagi manusia, dimana batas nyaman manusia berada pada kisaran $20,5{ }^{\circ} \mathrm{C}-27,1{ }^{\circ} \mathrm{C}$ (SNI-T-14-1993-03).

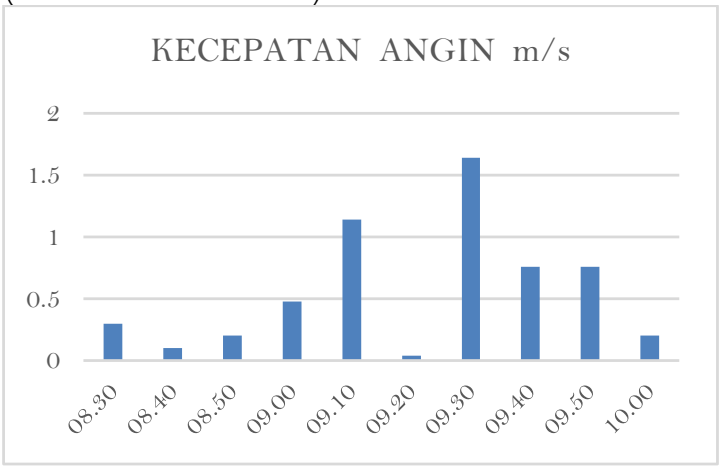

Gambar 7 Pergerakan Angin Pagi Hari

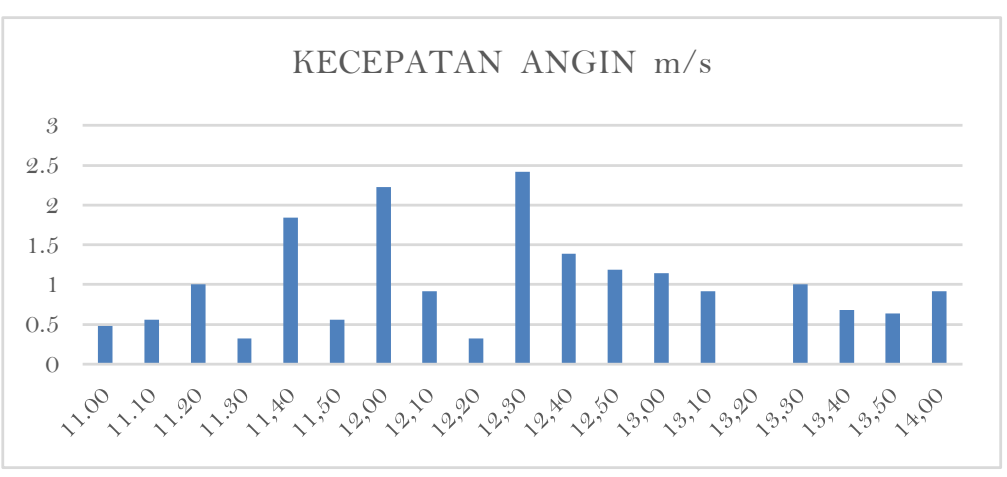

Gambar 8 Pergerakan Angin Siang Hari

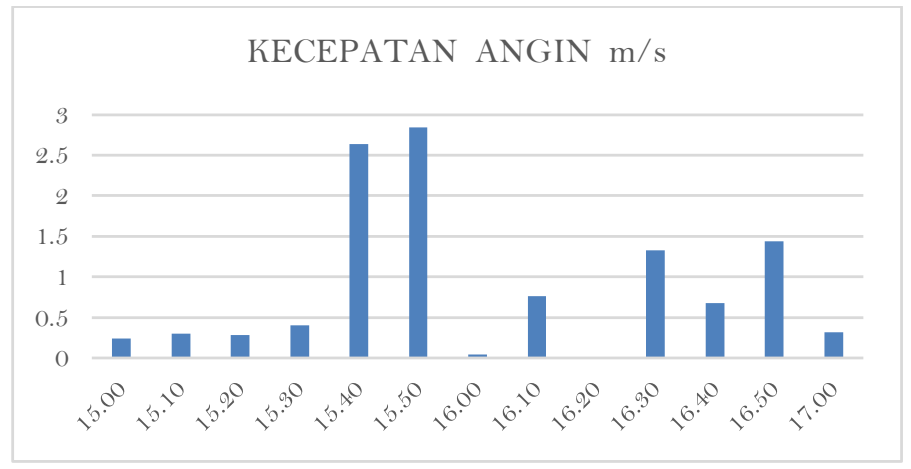

Gambar 9 Pergerakan Angin Sore Hari

Dari grafik di diatas terlihat bahwa kecepatan angin cenderung stabil dan cepat pada pagi hari yakni pukul 08.30 WIT - 09.10 WIT kemudian menurun dan meningkat lagi hingga pukul 10.00. Pergerakan angin di koridor pada siang hari fluktuatif, pada waktu-waktu tertentu tinggi dan sebaliknya. Pada sore hari, kecepatan angin mulai meningkat dan cenderung stabil. Hal ini sejalan dengan penurunan temperatur pada ruang koridor dan kelembaban udara yang bergerak naik. Berdasarkan pengamatan saat pengukuran berlangsung, peningkatan kecepatan angin terjadi saat beberapa kendaraan melewati pengamat dengan kecepatan tinggi dan jarak yang berdekatan sehingga mempengaruhi peningkatan kecepatan angin pada waktu itu. Selain itu, kecepatan angin 
tidak terlalu berpengaruh pada penurunan temperatur, sebaliknya ada peningkatan temperatur saat kecepatan angin meningkat. Hal terjadi karena angin yang berhembus membawa panas dari tempat yang dilewatinya. Pergerakan udara pada ruang koridor juga dipengaruhi oleh orientasi koridor yang memotong gerak angin dan konfigurasi ruangnya yang rapat dan tinggi dimana tidak adanya inlet-inlet yang cukup untuk dilewatinya.

\subsection{Analisis Kenyamanan Termal Pada Pengukuran Titik 2}

Teknik pengukuran data sama dengan pada pengukuran titik pertama. Pengukuran dilakukan pada 3 waktu yang berbeda yakni pagi (dimulai dari pukul 08.30 WIT sampai dengan pukul 10.00 WIT), siang (dari pukul 11.00 WIT sampai dengan 14.00 WIT) dan sore (mulai pukul 15.00 WIT sampai dengan 17.00 WIT).



Gambar 10 Data Pengukuran temperatur dan kelembaban pada titik 2 pukul 08.30-10.00 WIT



Gambar 11 Data Pengukuran temperatur dan kelembaban pada titik 2 pukul 11.00-14.00 WIT



Gambar 12 Data Pengukuran temperatur dan kelembaban pada titik 2 pukul 15.00-17.00 WIT 
Grafik-grafik (Gambar 10 s.d. Gambar 12) diatas menunjukan bahwa laju perubahan temperatur dan kelembaban udara tidak setinggi titik pengukuran sebelumnya. Pada pagi (08.30 WIT - 10.00 WIT) hari pukul 08.30 WIT temperatur udara berada pada $32,1^{\circ} \mathrm{C}$ hingga pukul 10.00 temperaturnya menjadi $32,4^{\circ} \mathrm{C}$, temperatur tertinggi pada interval waktu ini terjadi pada pukul 10.00 WIT yakni $32,4^{\circ} \mathrm{C}$. Temperatur rata-rata di titik pengukuran 2 ini lebih rendah jika dibanding dengan titik pengukuran 1 pada waktu yang sama dimana titik pengukuran 2 ratarata $31,76^{\circ} \mathrm{C}$ sedangkan titik pengukuran 2 rata-rata $33,58^{\circ} \mathrm{C}$. Kondisi ini tidak terjadi pada kelembaban udara, dimana titik pengukuran 2 rata-rata $69 \%$ sedangkan titik pengukuran 2 rata-rata $78,9 \%$. Jadi perubahan temperatur udara pada pagi hari di titik pengukuran ini lebih baik dari titik pengukuran sebelumnya. Sedangkan perubahan kelembaban udara pada pagi hari di titik pengukuran sebelumnya lebih baik dari titik pengukuran ini. Kondisi ini juga terjadi pada waktu pengukuran siang dan sore hari. Pergerakan angin di sekitar titik pengukuran 2 ini lebih baik jika dibandingkan dengan titik pengukuran 1. Rata-rata kecepatan angin di titik pengukuran 2 pada pagi, siang dan sore hari berturut-turut $0,71 \mathrm{~ms}, 1,79 \mathrm{~m} / \mathrm{s}$ dan 1,01 ms sedangkan pada titik pengukuran sebelumnya pada pagi, siang dan sore hari berturut-turut $0,56 \mathrm{~m} / \mathrm{s}, 0,96 \mathrm{~m} / \mathrm{s}$ dan $0,87 \mathrm{~m} / \mathrm{s}$.



Gambar 13 Pergerakan Angin Pagi Hari

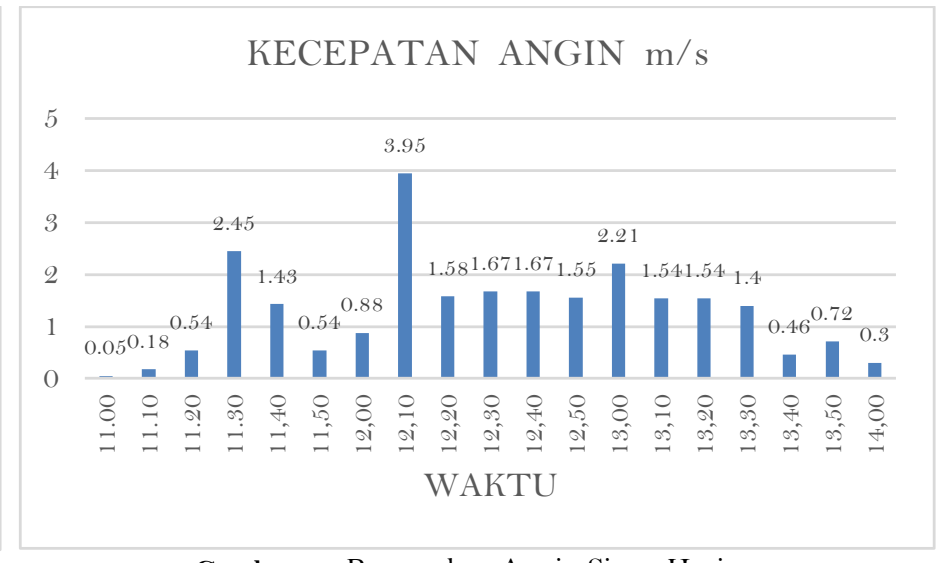

Gambar 14 Pergerakan Angin Siang Hari

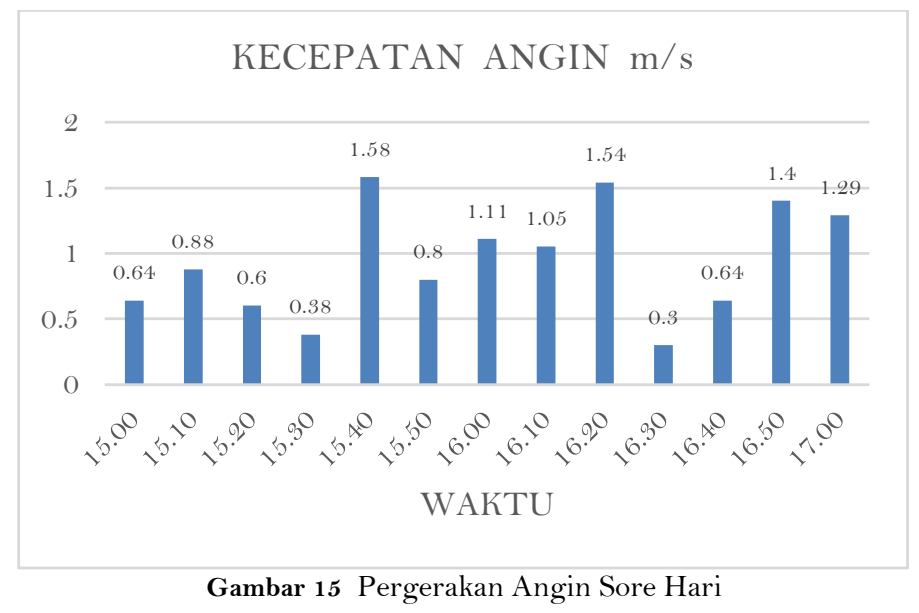

\subsection{Analisis Kenyamanan Termal Eksisting Koridor Menggunakan Envi-Met System}

Dari hasil simulasi menunjukan bahwa pada bagian koridor yang terdapat bangunan pada kedua sisinya dengan kerapatan rendah memiliki temperatur dan kelembaban udara yang lebih baik dibandingkan dengan bagian koridor yang memiliki kerapatan bangunan yang tinggi. Hal dimungkinkan karena pada bagian koridor yang memiliki kerapatan bangunan rendah di kedua sisinya angin bergerak sehingga dapat mengurangi panas akibat dari pemanasan material permukaan koridor oleh sinar matahari langsung. 


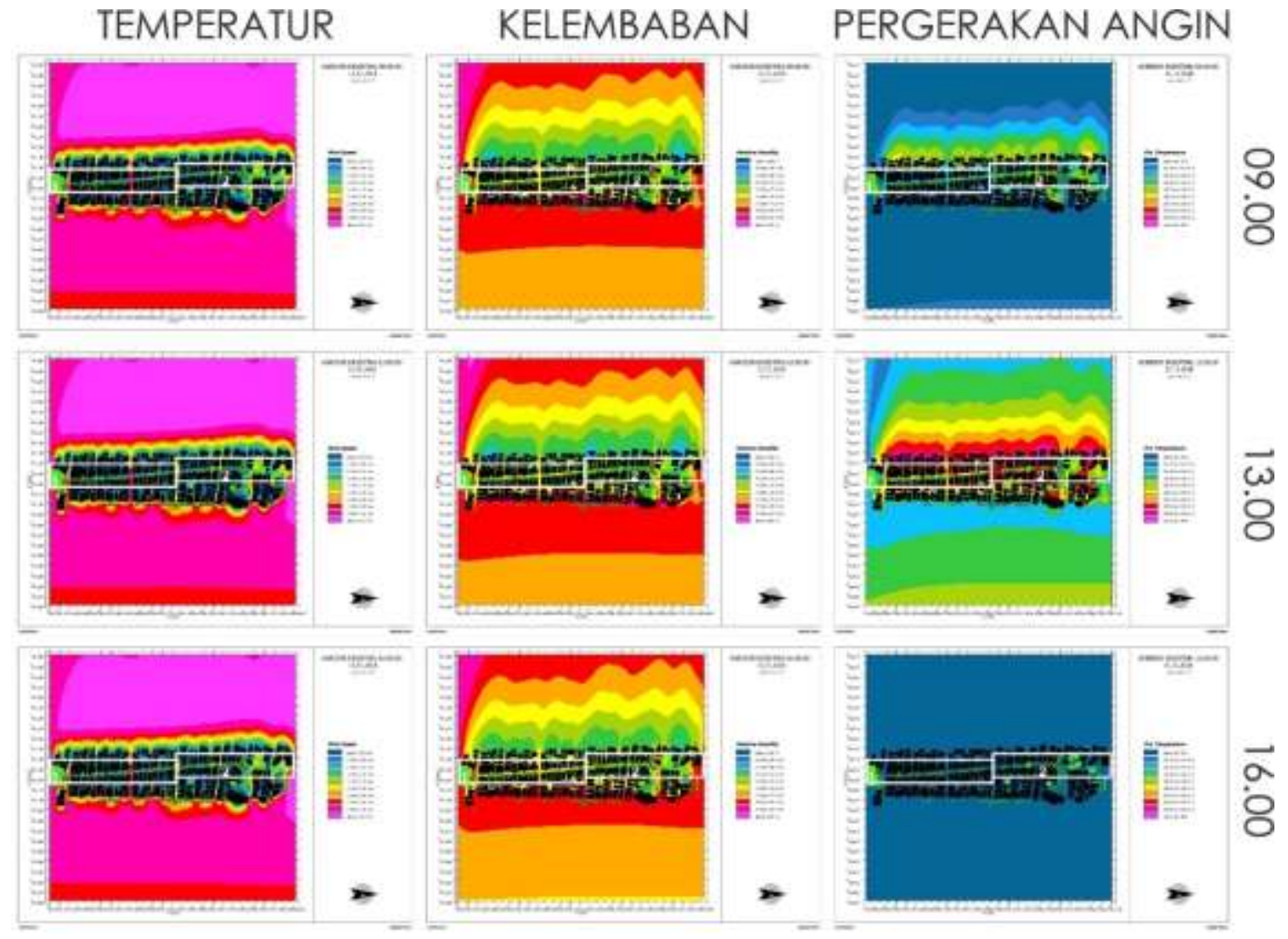

Gambar 16 Hasil Simulasi Termal Pada Koridor Sultan Khairun

\subsection{KESIMPULAN}

Hasil kesimpulan dari penelitian ini adalah koridor Sultan Khairun didominasi bangunan dengan ketinggian 1-2 lantai. Area Titik Pengukuran 1 minim vegetasi, temperatur rata-rata 34 derajat lebih panas pada siang hari. Sementara untuk Area Titik Pengukuran 2 vegetasi kedua sisi koridor jaraknya masih renggang dengan temperatur rata-rata 32 derajat dan siang hari lebih panas. Simulasi koridor dengan vegetasi rapat dan kerapatan bangunan rendah dikedua sisinya agar angin bergerak sehingga dapat mengurangi panas oleh sinar matahari.

\section{Ucapan Terima Kasih}

Terima kasih penulis ucapkan kepada LPPM Universitas Khairun yang telah membantu pendanaan Hibah Penelitian Tingkat Fakultas, sehingga penelitian ini dapat terlaksana.

\section{Daftar Pustaka}

[1] Lippsmeier, 1994. Bangunan Tropis. Jakarta: Erlangga.

[2] Satwiko, Prasasto. 2004. Fisika Bangunan 2. Yogyakarta: Penerbit Andi.

[3] Wong, N. H. (2009). Evaluation of the impact of the surrounding urban morphologyon building energy consumption. Singapore: National University of Singapore.

[4] Sugini. 2007. Model Kenyamanan Termal Termo Adaptif Psikologis pada Ruang Dalam Bangunan di Yogyakarta. Universitas Gadjah Mada: Yogyakarta. 